\title{
Assessing English Writing Skills of Students from Bilingual and Non-Bilingual Schools in Castilla-La Mancha, Spain A Comparative Study
}

\begin{abstract}
The teaching of foreign languages and the use of CLIL (Content and Language Integrated Learning) methodology is hugely popular in Spain nowadays. Many families are interested in this type of academic training because they are convinced the academic results are positive, but the question is whether it is in fact the case that foreign language level increases. The aim of this study was to analyse the different level of English writing skills of 4th grade students from both compulsory bilingual and non-bilingual secondary schools in Castilla-La Mancha (Spain). From the results of the study, we were able to examine whether bilingual programs help students improve their English writing skills as well as to compare the results obtained by bilingual schools in Castilla-La Mancha with those developed in other Spanish, or even European, regions.
\end{abstract}

Keywords: bilingual teaching, effectiveness, writing skill, compulsory secondary education

\section{Introduction}

Most bilingual programmes follow a CLIL (Content and Language Integrated Learning) methodology nowadays. The interest and credibility of this educational approach, well justified by Mohan in 1986, have increased over the last few years due to its usefulness as a means of learning another language in a natural way. The establishment of subjects taught in a foreign language through this methodology, focused more on the subject content learning than on language learning itself, is spreading increasingly throughout Spain. Several scientists 
such as Mehisto, Marsh, and Frigols (2008), Coyle, Hood, and Marsh (2010), and Marsh (2013), highlight the innovative power of this approach, even though its effectiveness varies depending on the context in which it is being developed.

There are numerous studies on the assessment of the use of CLIL methodology in the acquisition of foreign language communicative competence. Most of them show beneficial results (Lasagabaster \& Ruiz de Zarobe, 2010; Jiménez Catalán \& Ruiz de Zarobe, 2009; Villarreal \& García Mayo, 2009; Gallardo del Puerto et al. 2009; San Isidro, 2010; Hughes \& Madrid, 2011). Also, they revealed that bilingual programmes can help students raise their foreign language knowledge level. Nevertheless, do 4th grade Compulsory Secondary Education students who attend bilingual programme state schools in the Autonomous Community of Castilla-La Mancha get better results in the assessment of their English language writing skill than those who attend non-bilingual programme state schools? Our research focused on answering this question.

Throughout this paper several ideas have been discussed, namely, the first section introduces the origin of bilingual programmes in Castilla-La Mancha and presents the nature of the research. It explains the type of students involved, the tasks those students had to perform, and the place where these tasks were performed. The second section presents and analyses the results obtained in the test. The next section provides the comparison of the data with other Spanish and European regions where similar research has been developed. Finally, conclusions of our study regarding students' writing skills have been presented.

\section{Theoretical Background}

Bilingual teaching in Castilla-La Mancha started in 1996 with the introduction of the British Council-MEC Project in seven Pre-school and Primary Education Schools in addition to seven Secondary Education Schools. The Autonomous Community established its own bilingual teaching programme (Order 07/02/2005) with the creation of 36 "European sections" in 2005. This initiative coincided with the beginning of other bilingual programmes in monolingual Spanish regions, such as Madrid, Extremadura, and Andalucía, which started to develop their own bilingual programmes the same year (Nieto Moreno de Diezmas \& Ruiz Cordero, 2018). The last of these regions, for example, introduced a plurilingual development program through the Order BOJA 05/04/2005.

Afterwards, the regulation of bilingual teaching was modified in 2014 through the Order 16/06/2014. Subsequently, the "European sections" were called "linguistic programmes." This regulation, which still applies, establishes three types of linguistic programmes: (1) Introduction programmes, in which the 
content subject is taught completely in the foreign language; (2) Development programmes, in which only two content subjects are taught in a foreign language; (3) Excellence programmes, in which three content subjects are taught in the foreign language and at least one of the teachers must show proof of a C1 language level according to the European Framework. However, the new Decree 47/2017 became effective in the school year 2018/2019. Its aim is the implementation of a unique programme through which pre-schools and primary schools can teach content subjects using the foreign language they determine. The amount of time they have to do so is no less than 200 minutes in each of the levels of pre-primary education grades, and between $25 \%$ and $50 \%$ of the daily schedule in each of the primary education grades. The amount of time devoted to this way of teaching in secondary school varies from $30 \%$ to $50 \%$ of the daily schedule. Additionally, this law applies in high schools and in basic professional training (medium and higher level grades), where the amount of time allotted to learning content subjects in the chosen language of the school varies from $20 \%$ to $50 \%$ of the total daily schedule in each of the grades.

The number of bilingual schools has increased since the commencement of bilingual programmes. Currently, the goal of the above-mentioned new rule is to incorporate bilingual teaching in all non-university grades in Castilla-La Mancha. In fact, Castilla-La Mancha had 599 linguistic programmes established in 520 primary and secondary schools in the school year 2017/2018. These linguistic programmes are distributed among the five regions that make up the Autonomous Community and are as follows: Toledo, with the highest number of linguistic programmes, followed by Ciudad Real, Albacete, Cuenca, and Guadalajara.

The foreign language most frequently used in the bilingual teaching programmes in Castilla-La Mancha

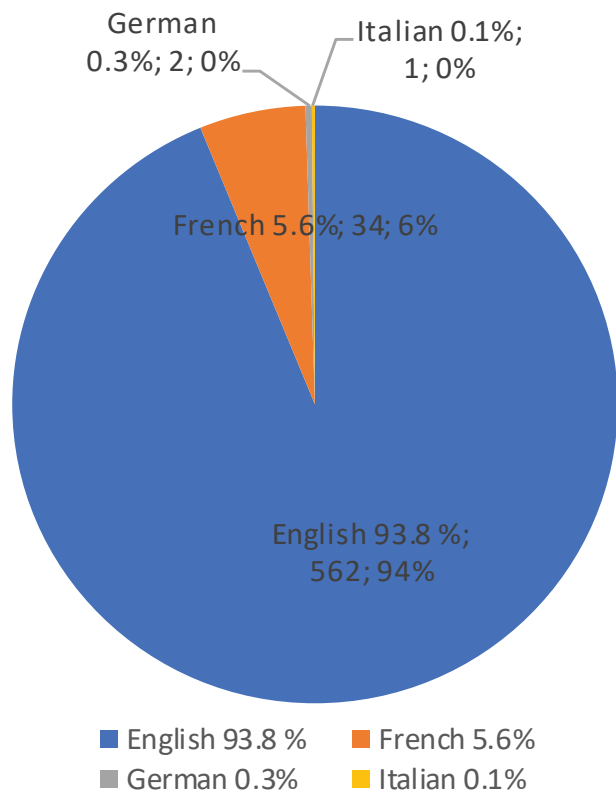

Figure 1. Percentage of Linguistic Programme Languages in Castilla-La Mancha in the 2017/2018 school year. Source: author's own elaboration. is English. Out of the 599 linguistic programmes in the school year 2017/2018, 562 programmes were conducted in English, 34 programmes in French, one programme in Italian, and two programmes in German (Figure 1). 


\section{Study}

\section{Methodology}

The present study intended to test and compare the level of English writing skills of 4th grade students of compulsory secondary education state schools (hereafter as CSE) with and without linguistic programmes in Castilla-La Mancha (Spain). Once the main objective of this paper was defined, the following research questions were addressed:

1. Is the level of English writing skills of compulsory bilingual secondary schools students higher than the one of those attending non-bilingual secondary schools in Castilla-La Mancha (Spain)?

2. Do the bilingual programs help students improve their English writing skills?

3. Are the results obtained in Castilla-La Mancha (Spain) similar to those developed in other Spanish and European regions?

To carry out the study a few interesting methodology ideas have been explained. First of all, the characteristics of the participants taking part in this study have been outlined. Secondly, we focus on the way in which the schools these students attend have been chosen. Next, a description of the instrument (the writing test the students in 4th grade CSE take, from both bilingual and non-bilingual schools, as well as the assessment criteria adopted to reach these results) has been provided. With the information obtained from this analysis, we were able to answer the research questions.

\section{Participants}

Two hundred and one 4th grade CSE 15- and 16-year-old students took part in this test. Seventy-three of them receive bilingual tuition in secondary education schools, whereas 128 attend non-bilingual secondary education schools. The students' cultural and socioeconomic levels vary, regardless of the fact whether they come from rural or urban areas.

The students were asked to complete a writing test (see section Instruments). They belong to eight different secondary education state schools in the Autonomous Community of Castilla-La Mancha. Four of the secondary schools have bilingual linguistic programmes and the remaining four do not. Bearing in mind that the students attend schools that offer different linguistic programmes, we were able to test the different foreign language writing skill levels of the two groups of students. All the participants were tested anonymously, as they provided their class number only, and, what is more, they were unaware that the tests would be used for research. They thought it was just 
to know their English level. As a result, the test was completed in a relaxed, non-pressurised manner.

As far as the tested students' previously acquired English language knowledge is concerned, it must be highlighted that all the students attending bilingual programme secondary education schools come from primary education schools with bilingual systems operating from, at least, 3rd grade primary education. Therefore, these students are considered "bilingual" as for eight years their language of instruction was English and, in fact, they had three times more English than their counterparts in non-bilingual programme schools. This implies that, apart from the subject of English Language, the bilingual programme school students have attended, at least, two other content subjects where English is the medium of instruction through a CLIL methodology. According to some of the students' teachers, many of these students also attend private English lessons outside school. In contrast, such private English tuition after school for those students attending non-bilingual schools is minimal, even though it is important to mention that most students have access to resources at home, such as the internet, allowing them constant contact with English. These data were supplied by teachers from the schools partaking in this research.

\section{Secondary Schools}

Some students from eight high schools were chosen randomly to be tested on English language writing skills in Castilla-La Mancha. The schools' participation in this project has been voluntary. Therefore, it is a randomized sample in which four bilingual schools decided to participate in the study. The four high schools concerned were matched to other non-bilingual high schools with similar features (depending on the type of students, sociocultural level, rural or non-rural area, size and proximity to the schools).

\section{Instruments}

The instrument used has been a writing test. The writing test was designed to test the level of the writing skill of a few students in 4th grade CSE from Castilla-La Mancha. The level of the assignment was that of PET (Preliminary English Test), which is equivalent to an intermediate level of English language. The test, which can be seen in Annex I, is consistent with the B1 level of the CEFR (Common European Framework of Reference) as shown in Table 1.

We asked for help with the "English Language Assessment" for the completion of this test in the school year 2017/2018 with the aim of making the data collection as objective as possible. This is the linguistic assessment supplier 


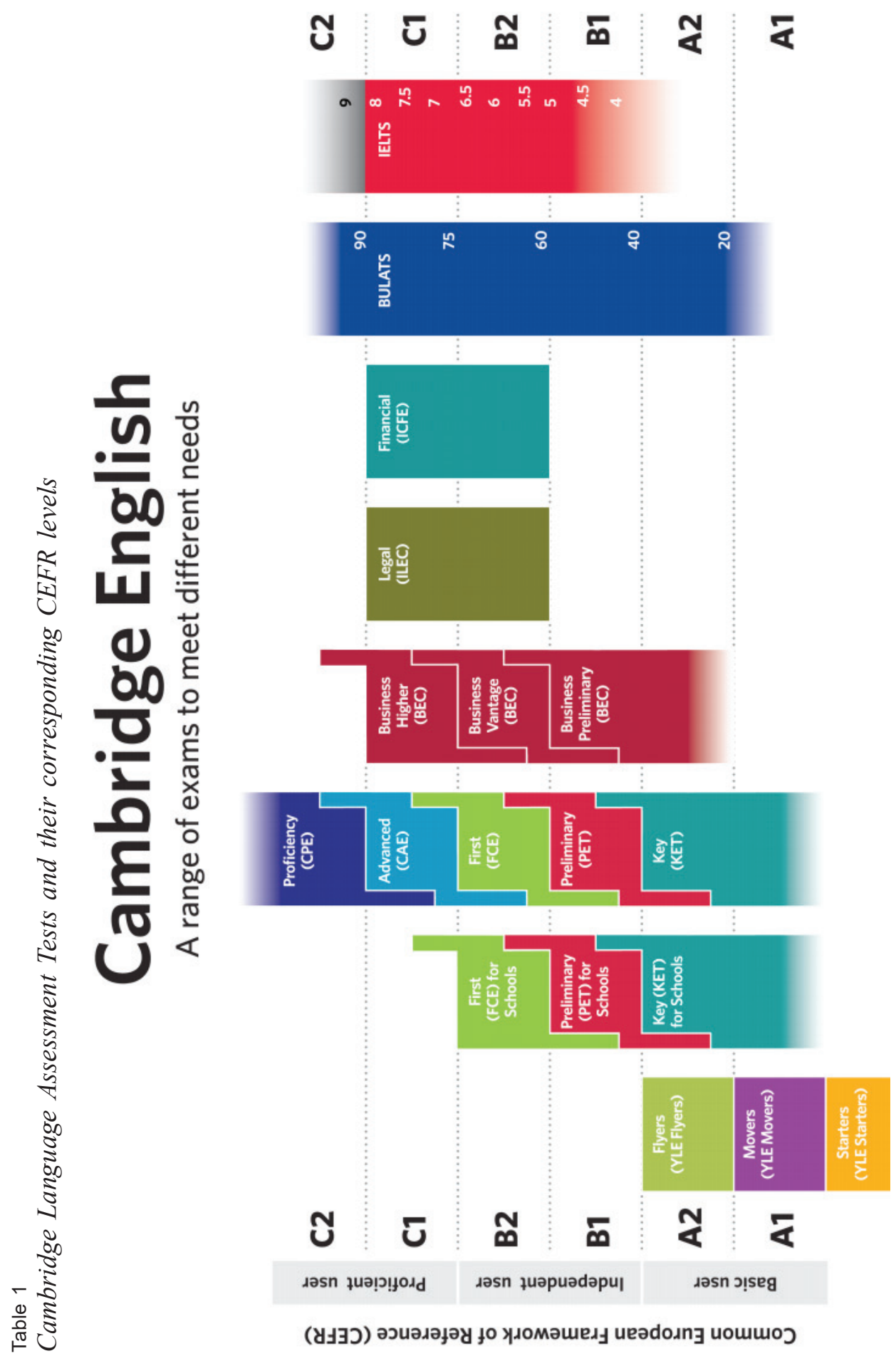


that relies on the biggest research team exclusively devoted to the development and control of the quality of their tests. In Table 1, which is seen as follows, both the tests developed by this institution and their level according to the CEFR can be seen.

The test the students took included three activities:

- The first activity (Annex 1: writing. Part 1). The student has to rewrite a sentence using the word provided.

- The second activity (Annex 1: writing. Part 2). Students are asked to write a postcard to their friend Sam, with whom they have just spent a few days, telling him how the trip back home was, what they enjoyed the most from their time together and inviting him to visit them. The length of words can be between 35 and 45 words.

The third activity (Annex 1: writing. Part 3). The students must choose one of the two topics. These topics were: answering a friend's letter you have received in which he or she asks you for help writing about a special day people celebrate in your country, and/or writing a story in the past tense starting with "Jo looked at the map and decided to go left." The length of words must be around 100 . The examinees had an hour to complete the three activities, and they could get up to five points for each one. Therefore, the maximum score they could get in this writing category was a total of 15 points. Next, the criteria used to assess the writing activities have been listed in Table 2 .

Table 2

Assessment criteria used to grade the writing activities

Assessment criteria (each activity)

\begin{tabular}{lc}
\hline \multicolumn{1}{c}{ Criteria } & Mark \\
\hline Relevant content & 5 points maximum \\
\hline Communicative & 5 points maximum \\
\hline $\begin{array}{l}\text { Organization and use of linking } \\
\text { words }\end{array}$ & 5 points maximum \\
\hline $\begin{array}{l}\text { Language: correct use of vocabu- } \\
\text { lary and grammar }\end{array}$ & 5 points maximum \\
\hline $\begin{array}{l}\text { The total mark for each of the writing activities adds up to } 20 \text { points. } \\
\text { These } 20 \text { points are reduced to their equivalent to a maximum of } 5 \\
\text { points for each writing activity. }\end{array}$ \\
\hline
\end{tabular}

It could be argued that this Cambridge Assessment test does not show the writing skill knowledge level of either bilingual or non-bilingual school students, either because they have not been trained to complete it or because the test has not been designed according to the CLIL methodology. Nevertheless, this statement is not applicable in either of the students' groups because all the learners are required to improve their writing skill through writing activi- 
ties in Compulsory Secondary Education as is stated in their foreign language learning study programme, no matter whether they attend bilingual or nonbilingual schools. This means that all the students should be trained for this type of writing test.

\section{Results}

Once the 201 tests with each of their three writing activities (see Annex I) were finished and checked according the assessment criteria mentioned above, the English language writing skills results for the bilingual and non-bilingual school students in Castilla-La Mancha were determined. The number of writing activities that meet the established criteria and, at the same time, the average mark of students who exceed these criteria in bilingual and non-bilingual schools are detailed in Table 3.

Table 3

Writing activity assessment criteria results

WRITING ACTIVITY RESULTS

\begin{tabular}{|c|c|c|c|c|}
\hline $\begin{array}{l}\text { Type of school / } \\
\text { Writing criteria }\end{array}$ & $\begin{array}{l}\text { Relevant } \\
\text { contents }\end{array}$ & Communicative & $\begin{array}{l}\text { Organization } \\
\text { and use } \\
\text { of linking words }\end{array}$ & $\begin{array}{l}\text { Language: } \\
\text { Vocabulary } \\
\text { and grammar }\end{array}$ \\
\hline $\begin{array}{l}\text { BILINGUAL } 1 \\
23 \text { students }\end{array}$ & 9 & 10 & 5 & 6 \\
\hline $\begin{array}{l}\text { BILINGUAL } 2 \\
23 \text { students }\end{array}$ & 22 & 22 & 15 & 12 \\
\hline $\begin{array}{l}\text { BILINGUAL } 3 \\
17 \text { students }\end{array}$ & 4 & 5 & 3 & 2 \\
\hline $\begin{array}{l}\text { BILINGUAL } 4 \\
10 \text { students }\end{array}$ & 6 & 7 & 2 & 2 \\
\hline AVERAGE & $56.16 \%$ & $60.27 \%$ & $34.24 \%$ & $30.13 \%$ \\
\hline $\begin{array}{l}\text { NON-BILINGUAL } 1 \\
41 \text { students }\end{array}$ & 6 & 12 & 5 & 5 \\
\hline $\begin{array}{l}\text { NON-BILINGUAL } 2 \\
28 \text { students }\end{array}$ & 6 & 8 & 4 & 4 \\
\hline $\begin{array}{l}\text { NON-BILINGUAL } 3 \\
37 \text { students }\end{array}$ & 5 & 6 & 4 & 4 \\
\hline $\begin{array}{l}\text { NON-BILINGUAL } 4 \\
22 \text { students }\end{array}$ & 16 & 19 & 7 & 7 \\
\hline AVERAGE & $25.78 \%$ & $35.15 \%$ & $15.62 \%$ & $15.62 \%$ \\
\hline
\end{tabular}


Looking at Table 3 carefully, it is clear that there was a higher number of writing activities done by students who come from bilingual schools. These English language writing activities showed more relevant content, higher communicative achievement, better organization, more correct usage of linking words and more varied and accurate vocabulary and English grammar. This can be seen, for example, in the bilingual students' use of the passive voice and conditional sentences. Accordingly, 56.16\% of bilingual school students were able to create English language writing activities with relevant content versus $25.78 \%$ among non-bilingual school students. As far as communicative achievement is concerned, it is evident that the results obtained are high among both bilingual and non-bilingual students. However, the results are higher in the bilingual school students' activities (60.27\% bilingual school students versus $35.15 \%$ nonbilingual school students). With reference to organization and the use of linking words and language, that is, English vocabulary and grammar criteria, the results obtained are low in both types of schools. Notwithstanding, the bilingual school students English language writing activities were better organized and had a greater command of English vocabulary and grammar than those done by non-bilingual school students. The most remarkable difference, according to the criteria related to organization and use of English, was that a very low number of non-bilingual school students used linking words correctly. Moreover, most non-bilingual school students' organization was poor, as a substantial number of them $(73 \%)$ wrote only a few sentences without any connections. The different results can be seen in Figure 2, which also helps confirm that the bilingual school students' writing activity levels in Castilla-La Mancha surpass those of non-bilingual school students' levels from the same region in all the assessed criteria.

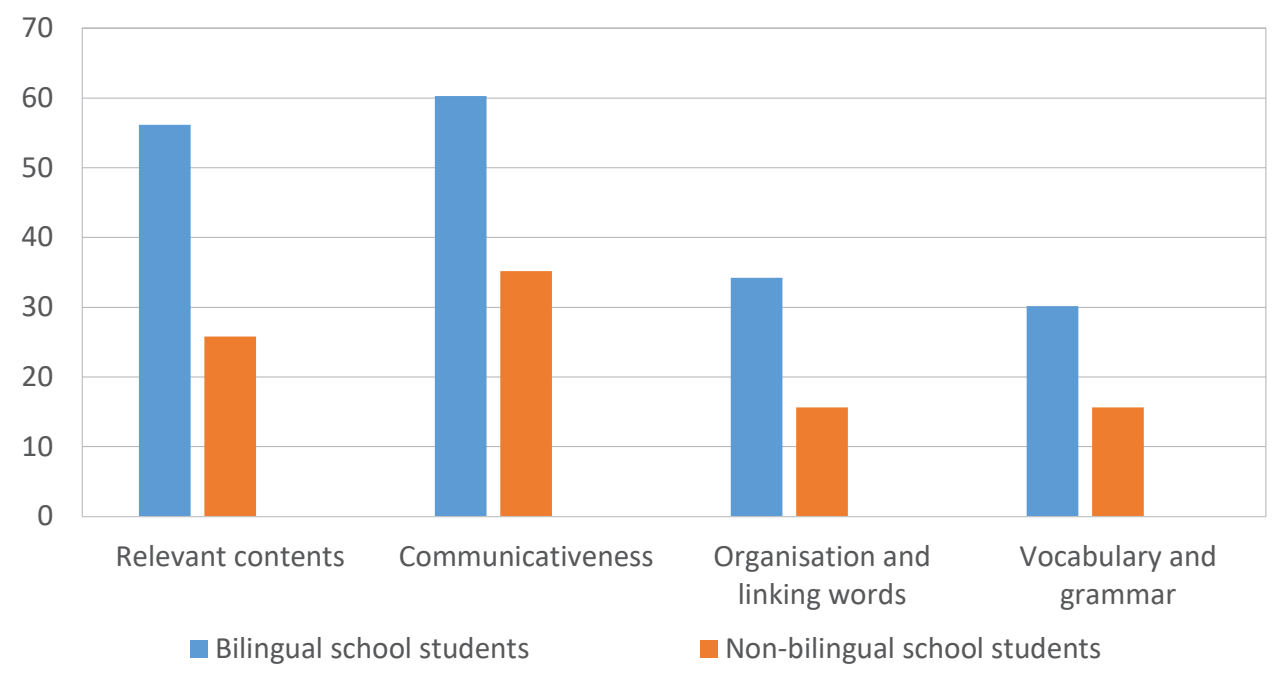

Figure 2. Bilingual and non-bilingual school students' writing activity comparison. 
Once the results were assessed and bearing in mind the assessment criteria used, we were able to ascertain the final mark of the English language writing activity each of the assessed schools obtained. Students in a bilingual school got an average mark of 51.7 points out of 100 points, whereas nonbilingual school students' average mark was 37.4 points out of 100 , as can be seen in Table 4. Even though the bilingual school students' mark is not very high (51.7 out of 100 points), it can be seen that the difference between them is 14.3 points. This information is very important since it implies a substantial difference between bilingual and non-bilingual school students. This is explained later.

Table 4

Writing activities final marks

\begin{tabular}{lc}
\multicolumn{1}{c}{ TYPE OF SCHOOL } & WRITING SKILL \\
\hline BILINGUAL 1 & 47.5 \\
\hline BILINGUAL 2 & 74.5 \\
\hline BILINGUAL 3 & 36.2 \\
\hline BILINGUAL 4 & 48.6 \\
\hline TOTAL & $\mathbf{5 1 . 7}$ \\
\hline & \\
\hline NON-BILINGUAL 1 & 35.3 \\
\hline NON-BILINGUAL 2 & 24.4 \\
\hline NON-BILINGUAL 3 & 24.3 \\
\hline NON-BILINGUAL 4 & 65.9 \\
\hline TOTAL & $\mathbf{3 7 . 4}$ \\
\hline
\end{tabular}

As the results obtained by the bilingual school students were not very high (51.7 points out of 100 points), we decided to make a comparison of the average marks and the median (the value representing the central position of an organized list of data). To do so, we need to calculate the standard deviation (SD) which is shown in Table 5. As we can see, both results are similar (2.73011 and 2.77870), which indicates that the results are equally distributed among the average marks.

After analysing average and medians, and with the goal of checking whether our study obtained data are significant or not, we went on to study the results the students achieved through the SPSS statistical test in order to compare all the average marks of all groups, bilingual or otherwise. The tool used to carry out this study was the independent sample T-Student with the average marks which the bilingual and non-bilingual school students achieved in their English 
Table 5

Average, medians and standard deviation table ( $N$ is the number of bilingual and non-bilingual school students)

\begin{tabular}{l|cc}
\hline TYPE OF SCHOOL & & WRITING \\
\hline BILINGUAL & Average & $\mathbf{5 . 3 7 4 1}$ \\
\hline NON-BILINGUAL & SD & 73 \\
& Median & 2.73011 \\
& Average & $\mathbf{3 . 5 2 6 6}$ \\
\hline & N & 128 \\
& SD & 2.77870 \\
\hline & Median & 3.2500 \\
\hline
\end{tabular}

writing skills activities. Table 6 shows that the comparison of the average marks obtained reveals that bilingual school students get results 1.8 points higher than the average marks achieved by the non-bilingual school students, whose $p=0.05$. The significance, or level of certainty we show in our statement, is provided by the $p$-value. In fact, this figure reveals the difference between 1 and the $p$ value. As this test was done with a $p$-value of 0.05 , the results we obtained show that the certainty we state for the average comparison is that of 0.95 or $95 \%$.

Table 6

Independent simple T-test of the average marks obtained by the bilingual and non-bilingual school students

\begin{tabular}{|c|c|c|c|c|c|c|c|c|c|c|}
\hline \multirow{2}{*}{\multicolumn{2}{|c|}{$\begin{array}{c}\text { T-test of the } \\
\text { average marks }\end{array}$}} & \multicolumn{2}{|c|}{$\begin{array}{l}\text { Leven's } \\
\text { test for the } \\
\text { equality of } \\
\text { variances }\end{array}$} & \multirow{3}{*}{$\mathbf{t}$} & \multirow{3}{*}{ gl } & \multicolumn{3}{|c|}{ Test $T$ for the equality of average } & & \\
\hline & & $F$ & Sig. & & & $\begin{array}{c}\text { Sig } \\
\text { (bilateral) }\end{array}$ & $\begin{array}{c}\text { Average } \\
\text { difference }\end{array}$ & $\begin{array}{c}\text { Difference } \\
\text { standard } \\
\text { error }\end{array}$ & \multicolumn{2}{|c|}{$\begin{array}{c}99 \% \\
\text { confidence } \\
\text { interval }\end{array}$} \\
\hline & & & & & & & & & Lower & Higher \\
\hline \multirow[t]{2}{*}{ Writing } & $\begin{array}{l}\text { Similar } \\
\text { variances } \\
\text { have been } \\
\text { accepted }\end{array}$ & .274 & .601 & 4.562 & 199 & .000 & 1.84755 & .40498 & .79429 & 2.90080 \\
\hline & $\begin{array}{l}\text { Similar } \\
\text { variances } \\
\text { have not } \\
\text { been } \\
\text { accepted }\end{array}$ & & & 4.584 & 152.106 & .000 & 1.84755 & .40302 & .79626 & 2.89884 \\
\hline
\end{tabular}

${ }^{1}$ Bear in mind that it can never be $100 \%$ true as that would be a universal truth, which does not exist in probability. 
Thus, it can be said that the difference found between the English language writing skill of bilingual and non-bilingual school students comes to 1.8 out of 10 points, which is equal to $18 \%$.

These results support the fact that the difference between English language writing skills of bilingual and non-bilingual school students in the Community of Castilla-La Mancha are statistically significant. Nonetheless, we consider that the bilingual school students' mark is low (51.7 out of 100 points) if we bear in mind the considerably high number of hours they are exposed to English language through English and content subjects included in the CLIL methodology. In addition to this, the mark is also low if we compare it to the results obtained by students in other Autonomous Communities different from Castilla-La Mancha.

\section{Comparison of the Results Obtained in the Autonomous Community of Castilla-La Mancha to Other Spanish and European Regions}

Once the English language writing skill results in Castilla-La Mancha were analysed, we then compared them to similar studies carried out in other regions of Spain and other Europen countries.

On the one hand, with reference to studies carried out in Spain, San Isidro (2009) accomplished a study in Galicia similar to ours in which he focused on secondary school students. San Isidro found a difference between bilingual and non-bilingual school students who achieved a writing skill level of $21.3 \%$. This difference is similar to the one we found in our research. Jiménez Catalán \& Ojeda Alba (2008) tested the English language vocabulary production of 86 6th grade primary education students belonging to CLIL and non-CLIL state-financed private schools in Logroño, La Rioja. The students from bilingual schools achieved an average mark of 4.54 out of eight points, compared with those from non-bilingual schools with an average mark of 3.63 out of eight points. Once again and consistent with our findings, the bilingual school students got higher marks than non-bilingual school students. In terms of morphosyntax, research by Villareal et al. (2009) must be taken into consideration. This study also confirms the results of the CLIL students' marks in relation to non-CLIL students' marks as far as tense and agreement are concerned, but not in all the assessed morphological signs.

On the other hand, there are some analyses such as that by Lorenzo et al. (2009) in Andalucía who studied 1320 primary and secondary education students, 754 of whom attended bilingual programme schools and 448, non-bilingual 
programme schools. These studies highlight the positive impact on the level of competence for both the bilingual school students' command of their mother tongue and the foreign language. In fact, the mark they got in the foreign language test was an average $24 \%$ higher than the non-bilingual school group's mark (Travé, 2013, p. 382). However, in terms of English language writing skills, this study is surprising because bilingual school students from Andalucía had a lower command in written skills, especially those attending primary schools. Additionally, we consider that these results are consistent with Whittaker's (2010) findings in the Autonomous Community of Madrid. This study confirmed that bilingual school students' writing can improve, but over time. In the same way, a number of studies that verify that English language writing skills are not developed in a meaningful way in CLIL contexts have led researchers, such as Dalton-Puffer (2011, p. 187), to hypothesize about the existence of a general writing competence which depends more on students' maturity than on the type of education institution in which students learn a foreign language. We can state that the 4th grade CSE bilingual students' writing skills have not improved a great deal in Castilla-La Mancha (even though they already have a certain cognitive maturity), because they scored only 51.7 out of 100 points on the assessment we made based on the Cambridge model.

País Vasco is another Spanish autonomous community that has been the focus of a number of research studies on bilingual and non-bilingual students' different English language levels. Lasagabaster (2008) and Ruiz de Zarobe (2010), for example, carried out a few studies whose results demonstrated that bilingual school students get higher marks in productive skill tasks such as writing. This is in contrast to Dalton-Puffer's theory, which states that a CLIL methodology enhances receptive skill tasks.

Navés \& Victori's studies (2010) in Cataluña demonstrate that the language level of students who learn through a CLIL methodology in their 8th grade exceed the language level of students who do not learn through such methodology in a higher grade (9th grade), including in writing skills (Sylvén, 2013, p. 301).

At the European level, it is important to mention Loranc-Paszylk's research (2009) in Poland. The level of competence among students studying the subject of European Integration History in the International Relations degree was analysed through CLIL methodology, as the course was done in English. Academic writing and reading were studied within integrated learning contexts for two semesters. The sample included 17 CLIL students and 35 students who learnt through their mother tongue, Polish. Once again, the benefits of integrating the foreign language and content in a determined subject were made clear after the English language writing skill test, which matches the results of our investigation.

Similarly, a report by Nikula (2005) in Finland showed that CLIL students exceed non-CLIL students' foreign language command. Despite the fact that the 
study does not break the communicative skills down, the former student group felt more confident than the latter when using the foreign language concerned. In Germany, Klippel (2003) and Zydatiss (2007) also asserted that, linguistically speaking, CLIL methodology is highly beneficial. However, a couple of studies do not share these findings and have not found this type of methodology so advantageous. In fact, Christiane Dalton-Puffer's studies in Austria (2007) demonstrated poorer results in writing skill level. Similarly, in Sweden, Sylvén (2004) concluded that what is really important in the foreign language learning process is the amount of exposure to that language outside the school context instead of learning through a CLIL methodology. Furthermore, Lim Falk (2008) supported this study and purported that students' interaction in CLIL lessons is more limited than in non-CLIL lessons (Sylvén, 2013, pp. 301-320).

\section{Conclusion}

The aim of this study was to examine whether CSE 4th grade students attending bilingual programmes in state schools in Castilla-La Mancha obtained better results in English language writing skills than students attending nonbilingual schools. Moreover, we also wanted to make a comparison between these results and those of students from other Spanish, and even European, regions in similar studies. As a result, following analysis of the data and comparisons made between the regions of Galicia (S. Isidro, 2009), La Rioja (Jiménez Catalán \& Ojeda Alba, 2008), Andalucía (Lorenzo et al. 2009), Madrid (Whittaker, 2010), País Vasco (Lasagabaster \& Ruiz de Zarobe, 2010), Cataluña (Navés \& Victori, 2010), Poland (Loranc-Paszylk, 2008), and Finland (Nikula, 2005), it can be said that students who attend bilingual schools achieve better results in writing skills activities than those who do not.

Statistically, even though the bilingual school students' results in CastillaLa Mancha are not very high-57.1 out of 100 points - they are $18 \%$ higher than the non-bilingual school students' results. The reasons why these results are different are various. First of all, students in secondary education attend bilingual programme schools voluntarily (Bruton, 2011). Normally, they get higher marks than their counterparts in English language activities (Grisaleña, Campo, \& Alonso, 2009), which is clearly an advantage. Secondly, it must be kept in mind that this study was carried out among students in their last grade of secondary education. Thus, we cannot forget that, as Dalton-Puffer (2011, p. 187) explains, writing skill competence is acquired on a long-term basis and is more dependent on the learner's maturity than on the type of foreign language instruction received. Next, there is no doubt about the fact that CLIL 
methodology (Mehisto, Marsh, \& Frigols, 2008; Coyle, Hood, \& Marsh, 2010; Marsh, 2013) and the frequent exposure to English language help students improve their communicative competence in this language. Therefore, according to this information, the bilingual school students' grades are higher than the non-bilingual school students' grades.

To conclude, even though we have made clear that the English language writing skill levels of bilingual school students are indeed higher than those of non-bilingual school students', it is necessary to highlight the need for improvements in the implementation of bilingual education programmes in Castilla-La Mancha (Nieto Moreno de Diezmas \& Ruiz Cordero, 2018). It should be the case that students who attend this type of foreign language programme get better results, given that they have been studying English language through a CLIL methodology for over eight years, thus, their exposure to the English language has been three times higher than that of their counterparts in non-bilingual school programmes (Moya Guijarro \& Ruiz Cordero, 2017).

While it is recognized that in spite of the fact that the development of bilingual programmes is not an easy task (Goodman, 2007), Castilla-La Mancha must now reconsider how bilingual programmes in schools can be improved in order to maximize their efficacy.

\section{References}

Barrios, M. E. (2011). Aprendizaje Integrado de Contenido y Lengua Extranjera. Retrieved from: http://ieselpalobilingual.wikispaces.com/file/view/AICLE_Elvira_Barrios-courseonline.pdf

BOJA de 22 de marzo de 2005, del Consejo de Gobierno, por el que se aprueba el Plan de Fomento del Plurilingüismo en Andalucía. Retrieved from: https://www.juntadeandalucia. es/boja/2005/65/5

Bruton, A. (2011). Are the differences between CLIL and non-CLIL groups in Andalusia due to CLIL? A reply to Lorenzo, Casal and Moore. Applied Linguistics, 32, 236-241.

Dalton-Puffer, C. (2007). Discourse in Content and Language Integrated Learning (CLIL). Amsterdam-Philadelphia: John Benjamins Publishing Company.

Dalton-Puffer, C. (2008). Outcomes and processes in Content and Language Integrated Learning (CLIL): current research from Europe. In W. Delanoy \& L. Volkmann (Eds.), Future perspectives for English language teaching (pp. 139-157). Heidelberg: Carl Winter.

Dalton-Puffer, C., Nikula, T., \& Smit, U. (2010). Charting policies. Premises and research on Content and Language Integrated Learning. In C. Dalton-Puffer, T. Nikula, \& U. Smit (Eds.), Language use and language learning in CLIL Classrooms (pp. 1-22). Amsterdam: John Benjamins Publishing Co.

Dalton-Puffer, C. (2011). Content and Language Integrated Learning: From practice to principle? Annual Review of Applied Linguistics 31 (pp. 182-204). Cambridge: Cambridge University Press. 
Decreto $7 / 2014$, de 22/01/2014, por el que se regula el plurilingüismo en la enseñanza no universitaria en Castilla-La Mancha.

Decreto 47/2017, de 25/07/2017, por el que se regula el plan integral de enseñanza de lenguas extranjeras de la comunidad autónoma de Castilla-La Mancha para etapas educativas no universitarias.

Grisaleña, J., Campo, A., \& Alonso, E. (2009). Enseñanza plurilingüe en centros de educación secundaria: análisis de resultados. Revista lberoamericana de Educación, 49(1), 1-12.

Harrop, E. (2012). Content and Language Integrated Learning (CLIL): Limitations and possibilities. Revista Encuentro, 21, 57-70.

Jiménez Catalán, R. M., \& Ojeda Alba, J. (2010). Disponibilidad léxica en inglés como lengua extranjera. Lenguaje y Textos, 30, 167-176.

Jiménez Catalán, R. M., \& Ruiz de Zarobe, Y. (2009). The Receptive Vocabulary of EFL Learners in Two Instructional Contexts: CLIL versus non-CLIL Instruction. In Y. Ruiz de Zarobe \& R. M. Jiménez Catalán (Eds.), Content and Language Integrated Learning. Evidence from research in Europe (pp. 81-92). Bristol: Multilingual Matters.

Lasagabaster, D. (2008). Foreign language competence in content and language integrated learning. Open Applied Linguistics Journal, 1, 31-42.

Lasagabaster, D. \& Ruiz de Zarobe, Y. (2010). CLIL in Spain. Implementations, results and teacher training. Newcastle: Cambridge Scholars Publishing.

Lim Falk, M. (2008). Svenska i engelskspråkig skolmiljö. Ämnesrelaterat språkbruk i två gymnasieklasser. Stockholm: Acta Universitatis Stockholmiensis.

Loranc-Paszylk, B. (2009). Integrating reading and writing into the context of CLIL classroom: Some practical solutions. International CLIL Research Journal 1(2), 46-53.

Lorenzo, F. (2010). CLIL in Andalusia. In D. Lasagabaster \& Y. Ruiz de Zarobe (Eds.), CLIL in Spain: implementation, results and teacher training (pp. 2-11). Newcastle: Cambridge Scholars Publishers.

Lorenzo, F., Casal, S., \& Moore, P. (2009). The Effects of Content and Language Integrated Learning in European Education: Key Findings from the Andalusian Bilingual Sections Evaluation Project. Applied Linguistics, 31(3), 418-442.

Mehisto, P., Marsh, D., \& Frigols M. J. (2008). Uncovering CLIL. Content and Language Integrated Learning in bilingual and multilingual education. Oxford: Macmillan.

Mohan, B. A. (1986). Language and content. Reading, MA: Addison Wesley.

Morales Osorio, J. F. (2017). Evaluación de la aplicabilidad del modelo AICLE en las escuelas bilingües colombianas (Doctoral dissertation). Universidad de Granada, España.

Moya Guijarro, A., \& Ruiz Cordero, M. B. (2018). Un estudio sobre la diferencia de nivel de competencia lingüística entre alumnos pertenecientes a centros bilingües y no bilingües en la comunidad autónoma de Castilla-La Mancha (España). Revista de Estudios Filológicos, $269-288$.

Navés, T. (2011). How promising are the results of integrating content and language for EFL writing and overall EFL Proficiency? In Y. Ruiz de Zarobe, J. Sierra, \& F. Gallardo del Puerto (Eds.), Content and Foreign Language Integrated Learning (pp. 103-128). Bern: Peter Lang.

Navés, T., \& Victori, M. (2010). CLIL in Catalonia: An overview of research studies. In Y. Ruiz de Zarobe \& D. Lasagabaster (Eds.), CLIL in Spain: Implementation, results and teacher training (pp. 30-54). Newcastle: Cambridge Scholars.

Nieto Moreno de Diezmas, E., \& Ruiz Cordero, B. (2018). Evaluación de los programas AICLE en Castilla-La Mancha. In J. L. Ortega-Martín, S. P. Hughes, \& D. Madrid (coords.), Influencia de la política educativa de centro en la enseñanza bilingüe en España. Madrid: MECDBritish Council, Secretaría General Técnica, Ministerio de Educación, Cultura y Deporte. 
Orden de 07/02/2005, de la Consejería de Educación y Ciencia, por la que se crea el programa de Secciones Europeas en centros públicos de Infantil, Primaria y Secundaria de la Comunidad Autónoma de Castilla La Mancha.

Orden de 16/06/2014, de la Consejería de Educación, Cultura y Deportes, por la que se regulan los programas lingüísticos de los centros de Educación Infantil y Primaria, Secundaria, Bachillerato y Formación Profesional sostenidos con fondos públicos de Castilla-La Mancha.

Ortega-Martín, J. L., Hughes, S. P., \& Madrid, D. (coords.) (2018). Influencia de la política educativa de centro en la enseñanza bilingüe en España. Madrid: MECD-British Council, Secretaría General Técnica, Ministerio de Educación, Cultura y Deporte.

Restrepo, A. P. M. (2012). Metodologías para la enseñanza de lenguas extranjeras. Hacia una perspectiva crítica. Revista Universidad EAFIT, 46(159), 71-85.

Ruiz de Zarobe, Y. (2010). Written production and CLIL: An empirical study. In C. DaltonPuffer, T. Nikula, \& U. Smit (Eds.), Language use and language learning in CLIL Classrooms (pp. 191-210). Amsterdam: John Benjamins Publishing Co.

Ruiz de Zarobe, Y. (2011). Which language competencies benefit from CLIL? An insight into applied linguistic research. In Y. Ruiz de Zarobe, J. Sierra, \& F. Gallardo del Puerto (Eds.), Content and Foreign Language Integrated Learning, (pp. 129-153). Berne: Peter Lang.

San Isidro, X. (2009). Galicia: Clil Success in a Bilingual Community. In D. Marsh, P. Mehisto, D. Wolff, R. Aliaga, T. Asikainen, M. J. Frigols-Martin, S. Hughes, \& G. Langé (Eds.), CLIL Practice: Perspectives from the Field (pp. 4-13). Jyväskylä. Jyväskylä: University of Jyväskylä.

San Isidro, X. (2010). An Insight into Galician CLIL: Provision and Results. In D. Lasagabaster \& Y. Ruiz de Zarobe (Eds.), CLIL in Spain: Implementation, results and teacher training (pp. 55-78). Newcastle: Cambridge Scholars.

Sylvén, L. K. (2013). CLIL in Sweden--Why does it not work? A metaperspective on CLIL across contexts in Europe. International Journal of Bilingual Education and Bilingualism, 16(3), 301-320. doi: 10.1080/13670050.2013.777387

Travé González, G. (2013). Un estudio sobre las representaciones del profesorado en Educación Primaria acerca de la enseñanza bilingüe. Revista de Educación, 361, 379-402.

Villareal, O., \& García Mayo M. P. (2009). Tense and agreement morphology in the interlanguage of Basque/Spanish bilinguals: CLIL versus non-CLIL. In Y. Ruiz de Zarobe \& R. M. Jiménez Catalán (Eds.), Content and Language Integrated Learning. Evidence from research in Europe (pp. 157-189). Bristol: Multilingual Matters.

Whittaker, R., \& Llinares, A. (2009). CLIL in social science classrooms: Analysis of spoken and written productions. In Y. Ruiz de Zarobe \& R. M. Jiménez Catalán (Eds.), Content and Language Integrated Learning. Evidence from research in Europe (pp. 215-234). Bristol: Multilingual Matters. 


\section{Annex 1}

\section{- Writing Part 1}

\section{WRITING TEST}

1. Last year, Niko was shown how to play basketball by his older brother.

Niko's older brother........................him how to play basketball last year.

2. Niko joined a basketball team three years ago.

Niko has been in a basketball team ....................... 3 years.

3. Niko practises at a stadium quite near his house.

Niko's house is not very....................from the stadium where he practises.

\section{- Writing Part 2}

You have just returned from a week's holiday staying at the home of your British friend, Sam.

Write a card to your friend. In your card, you should:

- tell Sam about the journey back to your home

- say what you enjoyed more about your stay

- ask Sam to visit you

Write 35-45 words on your answer sheet.

\section{- Writing Part 3}

Write an answer to one of the questions in this part.

Write your answer in about 100 words on your answer sheet.

\section{- Question 7:}

This is a part of a letter you receive from an English friend.

For my homework project I have to write about a special day that people celebrate in your country. Which special day should I write about? What information should I include?

Now write a letter to your friend.

Write your letter on your answer sheet.

\section{- Question 8:}

Your English teacher has asked you to write a story.

Your story must begin with this sentence:

Jo looked at a map and decided to go left.

Write your story on your answer sheet. 
María Begoña Ruiz Cordero

\title{
Bewertung der Schreibfertigkeit im Englischen \\ bei den Lernenden der zweisprachigen und nicht zweisprachigen Schulen in der Region Kastilien-La Mancha, Spanien Eine Vergleichsstudie
}

\begin{abstract}
Zusammenfassung
Fremdsprachenlernen und CLIL-Methoden (Content and Language Integrated Learning) sind derzeit in Spanien sehr beliebt. Viele Familien interessieren sich für diese Art der Bildung, weil sie von ihrer Wirksamkeit und Effizienz überzeugt sind. Vor diesem Hintergrund ist zu überprüfen, ob das Lernen, das auf der gleichzeitigen Vermittlung von Inhalten im Bereich der unterrichteten Fächer und der Elemente einer Fremdsprache beruht, das Niveau der Fremdsprachenkenntnisse von denjenigen erhöht, die daran teilnehmen. Ziel dieser Studie ist es, das unterschiedliche Niveau der Schreibfertigkeit im Englischen bei den Schülern der vierten Klasse der Oberschule zu analysieren, die das sowohl zweisprachige als auch nicht zweisprachige Pflichtprogramm für die Oberschulen in der Region Kastilien-La Mancha (Spanien) realisieren. Die Forschungsergebnisse lassen feststellen, ob zweisprachige Programme den Lernenden helfen, ihre Fertigkeit des Schreibens (der Textkomposition) im Englischen zu entwickeln, sowie die Ergebnisse, die durch zweisprachige Schulen aus der Region KastilienLa Mancha erzielt wurden, mit denen anderer Schulen in Spanien oder anderen europäischen Gebieten zu vergleichen.
\end{abstract}

Schlüsselwörter: zweisprachiger Unterricht, Effizienz, Schreibfertigkeit, obligatorische Schulbildung in der Oberschule 
